\title{
Effect of nicotine on serotonin (5-HT) levels in brain of depressed rats
}

\author{
Rahul R. Bhalsinge*, Anita A. Barde, Pratibha S. Worlikar, Manasi V. Limaye, \\ Mrunal P. Dhole, Abhijit V. Tilak
}

Department of Pharmacology, Dr. D.Y. Patil Medical College, Hospital and Research Centre, Pimpri, Pune, Maharashtra, India

Received: 01 February 2017

Revised: 05 February 2017

Accepted: 01 March 2017

*Correspondence to:

Dr. Rahul R. Bhalsinge,

Email:

rahulbhalsinge@gmail.com

Copyright: (C) the author(s), publisher and licensee Medip Academy. This is an openaccess article distributed under the terms of the Creative Commons Attribution NonCommercial License, which permits unrestricted noncommercial use, distribution, and reproduction in any medium, provided the original work is properly cited.

\begin{abstract}
Background: Reduction in brain serotonin (5-HT) levels contributes to depression. Nicotine may have antidepressant properties and smokers selfmedicate underlying depression. Epidemiological findings suggest that smokers more often demonstrate depressive symptoms than non-smokers and depressed patients are less likely to cease smoking. Therefore, the study was planned to evaluate the effect of nicotine on serotonin levels in brain of depressed rats.

Methods: Antidepressant action of study drugs was evaluated using isolation induced hyperactivity model in rats. Rats were divided into five groups with six rats in each group. Study groups: Vehicle in normal rats $1 \mathrm{ml} / \mathrm{kg}$ (subcutaneous); vehicle after isolation $1 \mathrm{ml} / \mathrm{kg}$ (subcutaneous); imipramine 10 $\mathrm{mg} / \mathrm{kg}$ (intraperitoneal) for 7 consecutive days; single dose of nicotine 0.4 $\mathrm{mg} / \mathrm{kg}$ (subcutaneous); single dose of nicotine $0.2 \mathrm{mg} / \mathrm{kg}$ (inhalational). Brain serotonin assay was carried out. The statistical significance was determined by ANOVA followed by Tukey test $(\mathrm{p}<0.05)$.

Results: Serotonin levels (55.93ng/g of brain tissue) in rats after isolation were significantly less than in normal rats $(335.87 \mathrm{ng} / \mathrm{g})(\mathrm{p}<0.001)$. In imipramine treated group, serotonin levels $(301.4 \mathrm{ng} / \mathrm{g})$ after isolation were highly significant as compared to serotonin levels in vehicle treated group after isolation $(\mathrm{p}<0.001)$. Nicotine administered by subcutaneous and inhalational route showed significantly higher brain serotonin levels, i.e. $175 \mathrm{ng} / \mathrm{g}$ and $254.62 \mathrm{ng} / \mathrm{g}$ respectively as compared to vehicle treated rats after isolation $(\mathrm{p}<0.001)$.

Conclusions: Single dose nicotine (inhalational) produced significant antidepressant action comparable to that of seven days' treatment of standard antidepressant drug imipramine in rats. In rats, nicotine by both routes i.e. subcutaneous and inhalational increased serotonergic activity.
\end{abstract}

Keywords: Depression, Isolation induced hyperactivity model, Nicotine, Serotonin

\section{INTRODUCTION}

Several researchers have studied interrelation between depression and smoking. A decrease in NA and 5-HT or both contributes to depression. Nicotine stimulates 5-HT release and smoking may be used by smokers to attenuate depression. Chronic smoking has been shown to inhibit MAO (monoamine oxidase) enzyme, thus producing antidepressive effects. ${ }^{1,2}$ Nicotine patches can improve the mood in depressed patients. ${ }^{3}$
However, it is unclear, if nicotine or other chemicals directly affect the brain of a depressed person. Nicotine may have antidepressant properties and smokers selfmedicate underlying depression. ${ }^{4,5}$ Epidemiological findings suggest that smokers more often demonstrate depressive symptoms than non-smokers and depressed patients are less likely to cease smoking. ${ }^{6}$

Therefore, use of nicotine analogues as a therapeutic agent for people with neurological and psychiatric diseases opens up new therapeutic advantages. ${ }^{1,7}$ The 
goal of this study is to evaluate effects of nicotine in depression via serotonergic pathway.

\section{METHODS}

Experimental protocol was approved by Institutional Animal Ethical Committee (IAEC). Wistar rats weighing 200-250 gm housed in polypropylene cages (single rat/cage) were used. They were fed pellet diet and water ad-libitum. The rats were maintained under standard conditions of temperature $\left(250^{\circ} \mathrm{C} \pm 50^{\circ} \mathrm{C}\right)$ and relative humidity $(55 \pm 10 \%)$. Rats of either sex were used. Rats were divided into five groups with six rats in each group.

\section{Design of experiment}

Antidepressant action of nicotine was studied in isolation induced hyperactivity model in rats. ${ }^{8}$ In this model of depression, adult Wistar rats were socially deprived for a period of 15 days. Rats were housed singly in cages $(38 \mathrm{~cm} \times 26 \mathrm{~cm} \times 20 \mathrm{~cm})$ without any visual or auditory contact with their normally housed counter parts for 15 days. After isolation, rats became hyperactive. This increase in locomotor activity was measured by using digital photoactometer. ${ }^{9}$ Nicotine $(0.2 \mathrm{mg} / \mathrm{kg})$ was administered by inhalational route using Electric dhoopdani. The study treatment was administered as shown in Table 1.

Table 1: Study treatment.

\begin{tabular}{|c|c|c|}
\hline Groups & Drug used & Dose \\
\hline \multicolumn{3}{|c|}{ Normal rats (Before isolation) } \\
\hline 1 & Vehicle & $1 \mathrm{ml} / \mathrm{kg}$ (s.c.) \\
\hline \multicolumn{3}{|c|}{ Depressed rats (After isolation) } \\
\hline 2 & Vehicle & 1ml/kg (i.p.) \\
\hline 3 & $\begin{array}{l}\text { Imipramine for } 7 \\
\text { consecutive days }\end{array}$ & 10mg/kg (i.p.) \\
\hline 4 & Nicotine (single dose) & $0.4 \mathrm{mg} / \mathrm{kg}$ (s.c.) \\
\hline 5 & Nicotine (single dose) & $0.2 \mathrm{mg} / \mathrm{kg}$ (inhal.) \\
\hline
\end{tabular}

For 5-HT neurotransmitter estimation, five groups were included with six rats in each groups. After seven days treatment of imipramine and single dose administration of nicotine, rats were sacrificed by cervical dislocation (according to CPCSEA guidelines, this method is acceptable for euthansia of laboratory animals). Whole brain was dissected and the tissue was homogenized in $0.1 \mathrm{ml} \mathrm{HCl}$-butanol $(0.85 \mathrm{ml} 37 \% \mathrm{HCl}$ in 1liter n-butanol for spectroscopy) for $1 \mathrm{~min}$ in a glass homogenizer. The sample was then centrifuged for $10 \mathrm{~min}$ at $2000 \mathrm{~g}$. An aliquot of the supernatant phase $(0.08 \mathrm{ml})$ was removed and added to an Eppendorf reagent tube (vol. $1.5 \mathrm{ml}$ ) containing $0.2 \mathrm{ml}$ heptane and $0.025 \mathrm{ml} \mathrm{HCl} 0.1 \mathrm{M}$. After $10 \mathrm{~min}$ of vigorous shaking, the tube was centrifuged under the same conditions as above in order to separate the two phases, and the upper organic phase was discarded. The aqueous phase $(0.02 \mathrm{ml})$ was then taken for 5-HT assay. All the above steps were carried out at $0^{\circ} .10$

\section{Serotonin assay}

Some modifications in reagent concentration became necessary, together with changes in the proportions of the solvents, in order to obtain a good fluorescence yield with the reduced volumes. For 5-HT determination, the ophthaldialdehyde (OPT) method was employed. From the OPT reagent $(20 \mathrm{mg} \%$ in conc. $\mathrm{HCl}) 0.025 \mathrm{ml}$ were added to $0.02 \mathrm{ml}$ of the $\mathrm{HCl}$ extract. The fluorophore was developed by heating to $100^{\circ} \mathrm{C}$ for $10 \mathrm{~min}$. After the samples reached equilibrium with the ambient temperature, excitation/emission spectra or intensity readings at $360-470 \mathrm{~nm}$ were recorded. ${ }^{10}$

\section{Statistical analysis}

The results were expressed as mean $\pm \mathrm{SD}$. The statistical significance was determined by one-way analysis of variance (ANOVA) followed by Turkey test, using Primer of Biostatistics $\mathrm{p}<0.05$ was considered to be statistically significant. ${ }^{11}$

\section{RESULTS}

Serotonin levels in normal rats were $335.87 \mathrm{ng} / \mathrm{g}$ of brain tissue. Levels of serotonin were significantly less in rats after isolation i.e. $55.93 \mathrm{ng} / \mathrm{g}$ as compared to normal rats $(p<0.001)$. Levels of serotonin after isolation in three study treatment groups i.e. imipramine, nicotine by subcutaneous and inhalational route were compared with that of levels of serotonin after isolation in vehicle treated groups (Table 2).

Table 2: Brain serotonin (5-HT) levels.

\begin{tabular}{|c|c|c|}
\hline Groups & Treatment & $\begin{array}{l}\text { 5-HT }(\mathrm{ng} / \mathrm{gm}) \\
\text { Mean } \pm \text { SD }\end{array}$ \\
\hline 1 & $\begin{array}{l}\text { Vehicle control } \\
\text { (normal rats) }\end{array}$ & $335.87 \pm 39.46$ \\
\hline 2 & $\begin{array}{l}\text { Vehicle control } \\
\text { (after isolation) }\end{array}$ & $55.93 \pm 14.54^{\# \# \#}$ \\
\hline 3 & $\begin{array}{l}\text { Imipramine }(10 \mathrm{mg} / \mathrm{kg}) \\
\text { for } 7 \text { consecutive days } \\
\text { (after isolation) }\end{array}$ & $301.4 \pm 9.95^{* * *}$ \\
\hline 4 & $\begin{array}{l}\text { Nicotine }(0.4 \mathrm{mg} / \mathrm{kg} \text { s.c.) } \\
\text { single dose } \\
\text { (after isolation) }\end{array}$ & $175 \pm 18.55^{* * *}$ \\
\hline 5 & $\begin{array}{l}\text { Nicotine }(0.2 \mathrm{mg} / \mathrm{kg} \\
\text { inhal.) single dose } \\
\text { (after isolation) }\end{array}$ & $254.62 \pm 22.7^{* * *}$ \\
\hline
\end{tabular}

\#\#\# = Comparison with vehicle control (normal rats) $(\mathrm{p}<0.001)$ $* * *=$ Comparison with vehicle control after isolation $(\mathrm{p}<0.001)$

In imipramine treated group, serotonin levels were significantly increased to $301.4 \mathrm{ng} / \mathrm{g}$ of brain tissue after isolation. This rise in serotonin levels in imipramine 
treated group was highly significant as compared to serotonin levels in vehicle treated group after isolation $(\mathrm{p}<0.001)$. Nicotine administered by subcutaneous and inhalational route increased serotonin levels to $175 \mathrm{ng} / \mathrm{g}$ and $254.62 \mathrm{ng} / \mathrm{g}$ of brain tissue respectively. Nicotine administered by subcutaneous and inhalational route showed significantly higher brain serotonin levels as compared to vehicle treated rats after isolation i.e. in depressed rats $(\mathrm{p}<0.001)$.

Serotonin levels in group receiving nicotine by subcutaneous route were significantly less as compared to serotonin levels in imipramine treated rats $(\mathrm{p}<0.001)$. Serotonin levels in group receiving nicotine by inhalational route was comparable with the imipramine group (Table 2).

\section{DISCUSSION}

Major depression is treated with drugs that inhibit the reuptake and metabolism of biogenic amines such as noradrenaline, serotonin and dopamine. Drugs like tricyclic antidepressants (TCAs) and selective serotonin reuptake inhibitors (SSRIs) do not exhibit either a faster onset of action or greater efficacy than their predecessors. ${ }^{12}$ Therefore, there are concerted efforts underway to develop antidepressants with possible advantages over currently used antidepressant drugs. ${ }^{13}$ Depressed smokers are more dependent on smoking and smoking cessation in these subjects is often followed by a depressive episode. ${ }^{14}$ Nicotine patches can improve the mood of depressed patients. ${ }^{15-17}$

Available reports regarding antidepressant action of nicotine are controversial. Smoking is the most common route by which nicotine is inhaled and the results of subcutaneous nicotine have been inconsistent in various studies on depression. Laura A Leon suggested that for the sake of precision in animal modeling, animal models like active avoidance, social isolation, learned helplessness, behavioral despair, genetic depression models would be important to evaluate the antidepressant activity of a new potential compound. ${ }^{18}$ Social isolation stress is a valuable stress paradigm for investigating the effects of chronic psychosocial stress on various pathophysiological alterations in animals. ${ }^{19}$

Therefore, we conducted this study that compared the effects of imipramine, a tricyclic antidepressant and nicotine. Nicotine was administered by subcutaneous as well as inhalational route. Before estimation of neurotransmitters in rat brain tissue, rats were isolated for 15 days which induced depression. In this group, serotonin levels were significantly decreased compared to normal rats. Increased levels of 5-HT (serotonin) were seen in groups treated with standard antidepressant drug imipramine and nicotine administered by inhalational and subcutaneous route.
Our study showed that effect of single dose of subcutaneous nicotine on 5-HT (serotonin) levels was of lesser magnitude than inhalational nicotine and imipramine individually. But increase in 5-HT seen with inhalational nicotine was found to be comparable with imipramine. ECT (Electroconvulsive therapy) is the only treatment available for acute episode of depression with suicidal tendency. The available standard antidepressant drugs i.e. TCAs and SSRIs have delayed onset of action. So, inhalational nicotine may have clinical advantage in such situation. Partial nicotine receptor (nAChRs) agonists varenicline, sazetidine and cytisine are potent partial agonists at $\alpha 4 \beta 2$ subtype but they have very low affinity for other nAChRs subunits like $\alpha 7$. They are used in the management of depression and they have delayed onset of action as that of standard antidepressant like TCAs and SSRIs and require longer duration for therapeutic benefit. $^{20,21}$ Future studies will explore the relationship between monoaminergic, serotonergic, GABAergic and cholinergic through central neuronal nicotinic acetylcholine receptor (nAchRs) system and should further clarify the potential mechanisms of nicotine involved in the neurotransmission in mood disorders.

In present study, it was observed that single dose of nicotine by inhalation showed faster onset of action in isolation induced hyperactivity model. Therefore, it is suggested that single dose of inhalational nicotinic analogues may be the drugs of future in the management of acute episode of depression with suicidal tendency. Although this study makes us aware of advantages of inhalational nicotine, it has some limitations. It did not estimate the concentration of nicotine inhaled by rat in the inhalational chamber. Also, rate and depth of respiration of animal, the concentration of nicotine responsible for pharmacological action were not estimated. Systemic concentration of nicotine in the rat at different time points was not calculated. Effect of repeated doses of nicotine was not studied.

\section{CONCLUSION}

Nicotine administered by both subcutaneous and inhalational routes increased serotonergic activity in rats. But single dose nicotine given by inhalation route produced statistically significant antidepressant action comparable to that of seven days' treatment of standard antidepressant drug imipramine in rats.

\section{ACKNOWLEDGEMENTS}

Authors would like to acknowledge Dr. S. N. Bodhankar for providing the facility to estimate of serotonin levels in brains of rats.

Funding: No funding sources Conflict of interest: None declared

Ethical approval: The study was approved by the Institutional Ethics Committee 


\section{REFERENCES}

1. Reus VI. Mental Disorders. In: Psychiatric disorders. Fauci AS, Braunwald E, Kasper DL, Hauser SL, Longo DL, Jameson JL, Loscalzo J, editors. Harrison's Principles of Internal Medicine. 17th ed. New York. McGraw-Hill, Medical Publishing Division; 2008.

2. Shirayama Y, Chaki S. Neurochemistry of the nucleus accumbens and its relevance to depression and antidepressant action in rodents. Curr Neuropharmacol. 2006;4(4):277-91.

3. Rafael J, Pascual S. Nicotine antidepressant effects as a predictor of response to desipramine or fluoxetine in non-smoking major depressed patients. Salud Ment. 2002;25(02):16-20.

4. Popik P, Krawczyk M, Kos T, Nalep I. Nicotine produces andidepressant-like actions: Behavioural and neurochemical evidence. Eur $\mathbf{J}$ Pharmacol. 2005;51:128-33.

5. Picciotto MR, Brunzell DH, Caldarone BJ. Effect of nicotine and nicotinic receptors on anxiety and depression. Neuroreport. 2002;13(9):1097-106.

6. Turner Jr, Castellano LM, Blendy JA. Nicotinic partial agonists varenicline and sazetidine-a have differential effects on affective behavior. J Pharmacol Exp Ther. 2010;334(2):665-72.

7. Baldessarini RJ. Drugs and treatment of psychiatric disorders. In: Hardman JG, Limbird LE, Gilman AG. editors. Goodman \& Gilman's the pharmacological basis of therapeutics. 10th ed. New York. McGrawHill, Medical Publishing Division; 2001.

8. Harmer CJ, Goodwin GM, Cowen PJ. Why do antidepressants take so long to work? a cognitive neuropsychological model of antidepressant drug action. Br J Psychiatry. 2009;195(2):102-8.

9. Rohan KJ, Lindsey KT, Roecklein KA, Lacy TJ. Cognitive-behavioural therapy, light therapy and their combination in treating seasonal affective disorder. J Affect Disord. 2004;80(2-3):273-83.

10. Tamboli AM, Rub RA, Ghosh P, Bodhankar SL. Antiepileptic activity of lobeline isolated from the leaf of Lobelia nicotianaefolia and its effect on brain GABA level in mice. Asian Pac $\mathrm{J}$ Trop Biomed. 2012;2(7):537-42.

11. Chiplonkar SA, Rao KV. In: Analysis of Variance. KV Rao, editor. Biostatistics: A manual of statistical methods for use in health, nutrition and anthropology. 2nd ed. New Delhi. Jaypee Brothers Medical Publishers (P) Ltd; 2007.

12. Skolnick P. Antidepressants for the new millennium. Eur J Pharmacol. 1999;375(1-3):31-40.

13. Skolnick P, Legutko B, Li X, Bymaster FP. Current perspectives on the development of non-biogenic amine-based antidepressants. Pharmacol Res. 2001;43(5):411-23.

14. Markou A, Kosten TR, Koob GF. Neurobiological similarities in depression and drug dependence: a self-medication hypothesis. Neuropsychopharmacol. 1998;18(3):135-74.

15. Salín-Pascual RJ, Drucker-Colín R. A novel effect of nicotine on mood and sleep in major depression. Neuroreport. 1998;9(1):57-60.

16. Salin-Pascual RJ, de la Fuente JR, Galicia-Polo L, Drucker-Colin R. Effect of transdermal nicotine on mood and sleep in nonsmoking major depressed patients. Psychopharmacol (Berl). 1995;121(4):4769.

17. Parrott AC. Cigarette derived nicotine is not a medicine. World J Biol Psychiatry. 2003;4:49-55.

18. Leon LA, Cardenas FP. Contribution of the dopaminergic system to the effect of chronic fluoxetine in the rat forced swim test. Psychol Neurosci. 2008;1(1):81-6.

19. Mitchell PJ, Redfern PH. Animal models of depressive illness: The importance of chronic drug treatment. Curr Pharm Des. 2005;11:171-203.

20. Turner JR, Castellana LM, Blendy JA. Nicotinic partial agonists varenicline and sazetidine-A have differential effects on affective behaviour. J Pharmacol Exp Ther. 2010;334(2):665-72.

21. Mineur YS, Eibl C, Young G, Kochevar C, Papke RL, Gündisch D, Picciotto MR. Cytisine-based nicotine partial agonists as novel antidepressant compounds. J Pharmacol Exp Ther. 2009;329(1):37786.

Cite this article as: Bhalsinge RR, Barde AA, Worlikar PS, Limaye MV, Dhole MP, Tilak AV. Effect of nicotine on serotonin (5-HT) levels in brain of depressed rats. Int $\mathrm{J}$ Basic Clin Pharmacol 2017;6:938-41. 